\title{
Evacuation of mixed populations from trains on bridges
}

Dederichs, Anne; Sørensen, Janne Gress

Publication date:

2012

Link back to DTU Orbit

Citation (APA):

Dederichs, A., \& Sørensen, J. G. (2012). Evacuation of mixed populations from trains on bridges. Abstract from 6th International Conference on Bridge Maintenance, Safety and Management, Stresa, Lake Maggiore, Italy.

\section{General rights}

Copyright and moral rights for the publications made accessible in the public portal are retained by the authors and/or other copyright owners and it is a condition of accessing publications that users recognise and abide by the legal requirements associated with these rights.

- Users may download and print one copy of any publication from the public portal for the purpose of private study or research.

- You may not further distribute the material or use it for any profit-making activity or commercial gain

- You may freely distribute the URL identifying the publication in the public portal

If you believe that this document breaches copyright please contact us providing details, and we will remove access to the work immediately and investigate your claim. 


\section{Evacuation of mixed populations from trains on bridges}

Anne S. Dederichs and Janne G. Sørensen

An understanding of human evacuation dynamics and performance are important when designing complex buildings such as bridges and applying performance-based codes in order to reduce the risk of exposing occupants to critical conditions in case of fire. Literature provides a number of case studies of real fire incidents as well as experiments concerning fire and evacuations []. The majority of previous studies deal with the evacuation behavior of homogeneous groups and applies normative standard. However, a significant part of the population is poorly described such as are people with impairments which are about $10 \%-21 \%$ of the world's population (Bendel, 2006), furthermore a mixed population comprehends elderly people , giving an additional 10\% (Bendel, 2006). In Denmark 20\% of the population are aged below 15 years (Danmarks statistik, 2011). In recent years a series of studies have focused on a broader population for experiments and models (Larusdottir, 2010). The discussion of "equal access" (Steinfeld, 1979) is slowly followed by the demand on "equal ergress" (Proulx, 1996). However, the passengers on trains on bridges are rarely homogeneous mixture. At the same time equal egress is far from assured today (Diament, 2009). This paper is on the evacuation of mixed populations from trains on bridges. The populations applied in the experiment are mixed corresponding to a composition corresponding to the population of Denmark.

\section{References}

Bendel, J., Decision Support System for Evaluating Accessibility of Facilities,The Israeli Journal of Occupational Therapy. Vol.15:3, 2006

Diament, M., Disaster plans do not address needs of those with disabilities, FIRE ENGINEERING 2009.

Larusdottir, A.R. and Dederichs, A.S.: Evacuation of Children: Movement on Stairs and on Horizontal Plane, Fire Technology: special issue 2010, Springer New York LCC, DOI: 10.1007/s10694-010-0177-6 (2010)

Proulx, G., Pineau, J., Review of Evacuation Strategies for Occupants with Disabilities; National Research Council Canada 1996. http://www.nrc-cnrc.gc.ca/obj/irc/

Steinfeld, E. Access to the Built Environment: A Review of Literature. Washington, D.C., US Dept. of Housing and Urban Development , Office of Policy Development and Research, April,1979 